\title{
"Desenvolvimento da Cultura de Humanização em Hospital Público de Grande Porte : Relato de Experiência "
}

\author{
Guimaraes, Nisia do Val Rodrigues Roxo; Santiago, Alessandra; Santos, Cleonice Bezerra dos; \\ Martins, Marcia; Francisco, Maria Cristina P.B.; Santos, Suely Luzia dos \\ Instituto Central do Hospital das Clínicas da FMUSP — nisia.guimaraes@hc.fm.usp.br
}

INTRODUÇÃO: Desenvolver a cultura da humanização em um hospital público de grande porte é um grande desafio para os profissionais envolvidos neste processo. na sua trajetória, a humanização do atendimento ao paciente sempre foi uma preocupação dos profissionais e gestores e reivindicação dos pacientes. Ações isoladas sempre foram desenvolvidas. o processo de sistematização da humanização teve o seu início em 2011 com a criação pelo Ministério da Saúde do Programa Nacional da Humanização da Assistência Hospitalar - PNHAH e em 2003 foi consolidada pela Política Nacional de Humanização - Humaniza SUS. em 2011, o Hospital cria a Rede Humaniza do Sistema Hospitalar e a partir daí são estabelecidas diretrizes para serem norteadoras das ações a serem desenvolvidas nas unidades num processo transformador da cultura institucional. Esta instituição possui 16 unidades médicas e cirúrgicas e 21 unidades de apoio, possui 890 leitos instalados, média de internação 3000 pacientes/mês Atende em média 100.000 pacientes/mês nos ambulatórios. Possui aproximadamente 6000 colaboradores. Devido à grandiosidade da instituição, esta unidade hospitalar também criou uma rede de humanização para desenvolver a cultura da humanização e monitorar suas ações. Esta rede esta subordinada à Diretoria Executiva e ao Conselho Diretor. OBJETIVOS: Criar a rede de humanização para desenvolver esta nova cultura no hospital. Coordenar e desenvolver ações de humanização alinhadas a Rede de Humanização do Sistema Hospitalar. Integrar a Unidade de Educação Permanente. Formar multiplicadores. Estimular ações para a melhoria da qualidade das relações humanas. MÉTODO: Planejamento e criação da rede com o apoio da Rede de Humanização do Sistema Hospitalar, Conselho Diretor e Diretoria Executiva. Escolha de colaboradores da equipe multidisciplinar de serviços estratégicos com perfil adequado para integrarem a rede. Disseminação da rede para as lideranças e inclusão dos colaboradores nos projetos de Humanização. Integração da rede na política de Educação Permanente RESULTADOS: Foi elaborado e aprovado o projeto da criação da rede pela Direx e Condir. $90 \%$ da liderança das unidades de apoio compareceram na reunião de disseminação da rede. $86 \%$ das unidades de apoio possuem representantes na rede.90\% das unidades de apoio possuem ações de humanização. $86 \%$ dos colaboradores das unidades de apoio foram capacitados em humanização.O hospital hoje conta com 33 projetos desenvolvidos nas unidades .Estes projetos estão classificados pelo âmbito da Ação: 27\% Ambiência,22\% Gestão, 15\% Ações Educativas e Educação Permanente, 15\% Acolhimento,9\%,Arte e Cultura, $9 \%$, Cuidado,3\% outros. CONCLUSÃO: Os resultados mostram que a humanização neste hospital vem desempenhando ações com a participação efetiva de seus colaboradores e a maior parte dos serviços desenvolvem projetos e possuem representantes na rede de humanização. a liderança apoia irrestritamente as ações e a humanização neste hospital passa a fazer parte do cotidiano da instituição, como educação permanente.Novos projetos envolvendo o paciente e colaborador estão sendo planejados e a cultura da humanização incorporada ao hospital.

Guimaraes, Nisia do Val Rodrigues Roxo; Santiago, Alessandra; Santos, Cleonice Bezerra dos; Martins, Marcia; Francisco, Maria Cristina P.B.; Santos, Suely Luzia dos. "Desenvolvimento da Cultura de Humanização em Hospital Público de Grande Porte :

Relato de Experiência ". In: Anais do Congresso Internacional de Humanidades \& Humanização em Saúde [= Blucher Medical Proceedings, num.2, vol.1]. São Paulo: Editora Blucher, 2014. ISSN 2357-7282

DOI 10.5151/medpro-cihhs-10514 